\title{
The effect of dietary energy and the inclusion of a $\beta$-adrenergic agonist in the diet on the meat quality of feedlot lambs
}

\author{
T.S. Brand ${ }^{1,2 \#}$, M.P. Genis ${ }^{2}$, L.C. Hoffman ${ }^{2}$, W.F.J. van de Vyver $^{2}$, R. Swart ${ }^{1}$ \& G.F. Jordaan ${ }^{2}$ \\ ${ }^{1}$ Elsenburg Institute for Animal Production, Dept. of Agriculture: Western Cape, Private Bag X1, Elsenburg, 7607 \\ ${ }^{2}$ Dept of Animal Sciences, Stellenbosch University, Private Bag X1, Matieland, 7602
}

(Received 3 September 2012; Accepted 11 October2013; First published online 26 October 2013)

\author{
Copyright resides with the authors in terms of the Creative Commons Attribution 2.5 South African Licence. See: \\ http://creativecommons.org/licenses/by/2.5/za/Condition of use: The user may copy, distribute, transmit and adapt the work, but must \\ recognise the authors and the South African Journal of Animal Science
}

\begin{abstract}
$\beta$-adrenergic agonists are commonly used in livestock production to enhance meat production and decrease the fat content of the body. $\beta$-adrenergic agonists normally improve growth performance. Recent increases in meat prices and the change in consumer preference towards leaner meat have resulted in more lamb producers opting to finish leaner mutton/lamb on farms in a feedlot system. The aim of this trial was to determine the effect of dietary energy, as well as the inclusion of a $\beta$-antagonist, on the meat quality of feedlot lambs. South African Mutton Merino lambs (108) of different sexes (rams and ewes) were weaned at 120 days of age and were randomly divided into six groups (18 lambs per group). The treatment consisted of three different dietary energy levels (high 12.7 MJ ME/kg feed, medium 12.0 MJ ME/kg feed and low 11.3 MJ ME/kg feed) with either the inclusion of a $\beta$-adrenergic agonist (zilpaterol hydrochloride) at $8.4 \mathrm{~g} /$ ton or not. Data were analysed according to a 3 (dietary energy) x 2 (inclusion of a stimulant) x 2 (sex) factorial analysis. No interaction occurred between treatments and the data were presented as the effect of dietary energy level, the inclusion of a stimulant and sex on proximate components, fat thickness and the tenderness of the meat. The factors $\beta$-adrenergic agonists and dietary energy level had no effect on the proximate components, fat thickness or the tenderness of the meat. The ewe lambs' $9-11^{\text {th }}$ rib-cut had a significantly higher fat content than the ram lambs (27.9\% vs. $23.1 \%$, respectively). Meat from ram lambs was less tender $(63.60 \mathrm{~N})$ compared to that from ewe lambs $(57.82 \mathrm{~N})$. Neither the inclusion of the $\beta$-adrenergic agonist $(59.8 \mathrm{~N}$ vs. $61.9 \mathrm{~N})$ nor the dietary energy level $(59.3 \mathrm{~N}$ vs. $63.5 \mathrm{~N}$ vs. $59.3 \mathrm{~N})$ had an effect on the tenderness of meat from lambs in this study.
\end{abstract}

Keywords: Meat quality, $\beta$-agonist, energy, South African Mutton Merino

\#Corresponding author: tersb@elsenburg.com

\section{Introduction}

The recent increase in mutton and lamb prices have resulted in many lamb producers opting to finish more lambs on farms in a feedlot system rather than marketing directly from the field. Another aspect that has also occurred in South Africa is where the sheep abattoirs have become more vertically integrated and are buying young weaned lambs and finishing them off in their own feedlot - which is often adjacent to the abattoir. All these producers are opting to minimize their input costs- which are predominantly made up of feed costs - in search for a better profit margin.

The livestock and meat industries are constantly on the lookout for alternative products to promote rapid and efficient growth while improving carcass characteristics and meat quality (Lopez-Carlos et al., 2010). $\beta$-adrenergic agonists ( $\beta$-AA) are known to increase muscle mass and decrease adipose tissue deposition in domesticated animals. The zilpaterol hydrochloride $(\mathrm{ZH})$ molecule is physiological highly active and acts on $\beta$-2 receptors in adipose tissue, smooth muscle and skeletal muscle (O'Neill, 2001). Shelver \& Smith (2006) mixed ZH into the diets of lambs; these lambs received $15 \mathrm{mg} / \mathrm{kg}$ BW/day (this level is also used by the industry). Ultimately Shelver \& Smith (2006) found that after a 2 day withdrawal 
period (or longer) an average of 5\% of the initial $\mathrm{ZH}$ concentration included in the diet was present in the edible tissue. As little data is available on the use of $\beta$-AA under South African sheep feedlot conditions, the aim of this trial was therefore to determine the effect of dietary energy as well as the inclusion of a $\beta$-antagonist on the meat quality of feedlot lambs.

\section{Material and Methods}

Lambs used in this trial were from Langgewens Experimental Farm, Western Cape, South Africa. South African Mutton Merino (SAMM) lambs (108) of different sexes (rams and ewes) were weaned at 120 days of age. These lambs were transported to Elsenburg Experimental Farm, Western Cape, South Africa, where they were vaccinated against pulpy kidney. The lambs were housed in pens (2 lambs/pen; the size of the pens are within the norm described by animal welfare guidelines; $(177 \mathrm{~cm} \times 117 \mathrm{~cm})$. Lambs were randomly divided into six groups (18 lambs/group). The treatments consisted of three different diets (Table 1) consisting of three energy densities: diet 1 (11.3 MJ ME/kg as is basis), diet 2 (12.0 MJ ME/kg as is basis) and diet 3 (12.7 MJ ME/kg as is basis) which included either the inclusion of a $\beta$-adrenergic agonist ( $\beta$-AA) at $8.5 \mathrm{~g} /$ ton or not (Figure 1). The lambs were fed in the feedlot for a period of approximately 6 weeks (40 days).

Table 1 Composition of the feedlot diets fed to lambs containing different dietary energy levels

\begin{tabular}{lccc}
\hline & \multicolumn{3}{c}{ Diets \% (as is) } \\
\cline { 2 - 4 } Ingredients & $\begin{array}{c}\text { \% Diet 1 } \\
\text { (11.3 MJ ME/kg } \\
\text { feed) }\end{array}$ & $\begin{array}{c}\text { \%iet 2 } \\
\text { (12.0 MJ ME/kg } \\
\text { feed) }\end{array}$ & $\begin{array}{c}\text { \% Diet 3 } \\
\text { (12.7 MJ ME/kg } \\
\text { feed) }\end{array}$ \\
\hline Maize & 44.30 & 54.90 & 65.50 \\
Lucerne & 40.00 & 25.90 & 11.80 \\
Cottonseed oilcake & 8.00 & 11.45 & 14.89 \\
Molasses powder & 2.50 & 2.50 & 2.50 \\
Salt (NaCl) & 1.00 & 1.00 & 1.00 \\
Bicarbonate of soda & 1.00 & 1.00 & 1.00 \\
Ammonium chloride & 1.00 & 1.00 & 1.00 \\
Limestone & 0.90 & 1.10 & 1.30 \\
Urea & 0.50 & 0.50 & 0.50 \\
MCP & 0.34 & 0.18 & 0.02 \\
Vit \& Min "Premix" & 0.25 & 0.25 & 0.25 \\
Sulphur & 0.20 & 0.20 & 0.20 \\
Growth promoters (Stafax, Tauratec \& Tylon) & 0.02 & 0.02 & 0.02 \\
\hline Total & 100 & 100 & 100 \\
\hline
\end{tabular}

Fresh, clean water was provided daily and feed were provided ad libitum to the lambs. Lambs and feed refusals were weighed weekly. The lambs were sheared before they were slaughtered after approximately 6 weeks in the feedlot. Lambs were weighted prior to transport to the abattoir from Elsenburg Experimental Farm. The lambs were slaughtered at a weight ( $\pm 54 \mathrm{~kg}$ ) higher than the average commercial weight ( $\pm 40 \mathrm{~kg}$ ) at which this breed is normally slaughtered so as to determine the effect of the $\beta$-AA. A registered sheep abattoir (Roelcor, Malmesbury, Western Cape, South Africa) was used to slaughter the lambs, using standard South African techniques. The cold carcasses weights were obtained two days after slaughter to calculate the dressing percentage of the lambs. 


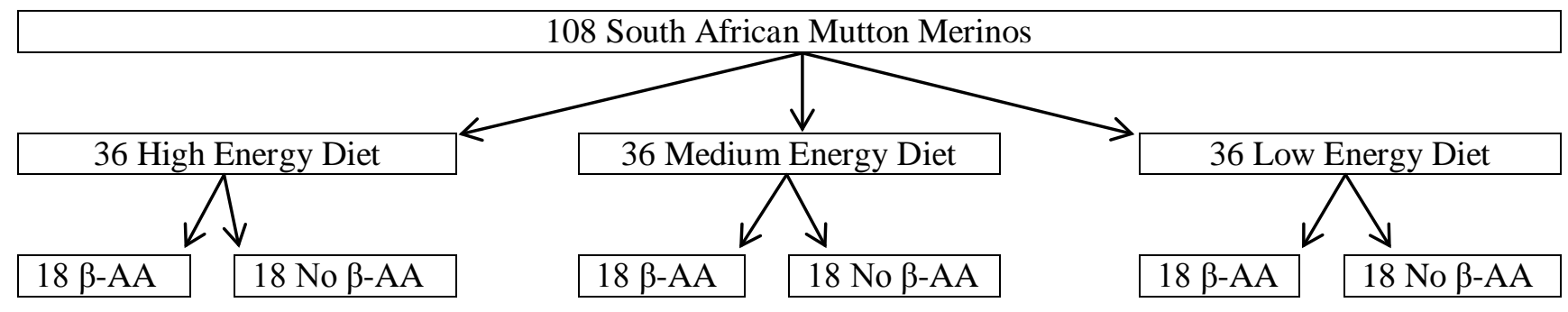

Figure 1 Schematic presentation of trial.

On the day of slaughter the muscle, longissimus dorsi (LD), with the subcutaneous fat (SCF) was removed from the 3-rib-cut $\left(9-11^{\text {th }}\right.$ rib), vacuum sealed and frozen until further analyses. The LD was cut up in $1.5 \times 1.5 \mathrm{~cm}$ thick slices. The colour, drip loss and cooking loss were measured on these slices. The combined rest of the LD and SCF was homogenised for proximate chemical analyses, using standard laboratory techniques (AOAC, 2002). The cooked slice (cooked for one hour at $80^{\circ} \mathrm{C}$ ) that was used for the determination of cooking loss was used to determine the tenderness of the meat. Meat tenderness was measured by means of the Warner-Bratzler (three cylindrical core samples of $1.27 \mathrm{~cm}$ diameter) shear force using standard parameters (Safari et al., 2001).

A digital calliper was used to measure the thickness of the subcutaneous fat on the LD muscle on both the caudal and cranial side of the 3-rib cut, $2 \mathrm{~cm}$ in from the midline.

The experiment consisted of a completely randomised design with six treatments (dietary energy level with either the inclusion or absence of a $\beta$-AA. The treatment design was a $3 \times 2 \times 2$ factorial with dietary energy level (low, medium and high), the provision of a $\beta$-AA (included or absent) and sex (rams and ewes) as the main factors.

A factorial analysis of variances was performed on the data using SAS for windows version 9.1.3 Proc GLM (SAS, 2000), whereas normality was tested with the Shapiro-Wilk test (Shapiro \& Wilk, 1965). Outliners were removed, which caused deviations from normality, before the final analyses. Student's tLeast Significant Differences (LSD) was calculated at the 5\% significance level to compare treatment means.

\section{Results and Discussion}

No interaction occurred between the treatments and the data is presented as the effect of dietary energy (low, medium and high), $\beta$-agonist (provided in the diet or not) and sex (rams and ewes) on the fat thickness, percentage of moisture, protein, fat and ash in the meat as well as the tenderness of the meat.

An increase in dietary energy level has been noted to result in an increase in fat deposition (Summers et al., 1978; Ebrahimi et al., 2007). However, the meat fat levels (thickness and chemically determined) of the SAMM were not affected by the different dietary energy levels (Table 2). Similarly, dietary energy levels had no influence on meat tenderness (Table 2). None of the other proximate components (protein, moisture and ash percentages), nor the thickness of the fat was influenced by the different dietary energy levels.

Although $\beta$-agonists have been reported to cause tougher meat (Kretchmar et al., 1990; Wheeler \& Koohmaraie, 1992), the growth stimulant had no effect in this trial (Table 3). Tenderness of meat is a major factor contributing to the eating quality and consumer preference (Hopkins \& Fogarty, 1998; Safari et al., 2001). The use of a $\beta$-agonist normally decreases adipose tissue and increases skeletal muscle deposition (Mersmann, 1998; 2002; Lopez-Carlos et al., 2010). There was, however, no difference in the fat content of the meat between the groups that received the $\beta$-AA and those that did not (Table 3 ). This could be contributed to the fact that there were very small differences in the energy content of the diet (11.3 MJ $\mathrm{ME} / \mathrm{kg}$ as is vs. $12.0 \mathrm{MJ} \mathrm{ME} / \mathrm{kg}$ as is vs. $12.7 \mathrm{MJ} \mathrm{ME} / \mathrm{kg}$ as is). 
Table 2 Least square means ( \pm s.e.) depicting the effect of dietary energy on meat quality of SA Mutton Merinos fattened off in a feedlot

\begin{tabular}{lccr}
\hline & & Energy levels & \\
\cline { 2 - 4 } Parameters & Low & Medium & High \\
\cline { 2 - 4 } Drip loss (\%) & $0.77^{\mathrm{a}} \pm 0.04$ & $0.83^{\mathrm{a}} \pm 0.04$ & $0.80^{\mathrm{a}} \pm 0.04$ \\
Cooking loss (\%) & $17.32^{\mathrm{a}} \pm 0.83$ & $17.11^{\mathrm{a}} \pm 0.84$ & $16.61^{\mathrm{a}} \pm 0.83$ \\
L $^{*}$ & $36.19^{\mathrm{a}} \pm 0.48$ & $35.24^{\mathrm{a}} \pm 0.50$ & $36.89^{\mathrm{a}} \pm 0.49$ \\
$\mathrm{a}^{*}$ & $12.81^{\mathrm{a}} \pm 0.26$ & $13.64^{\mathrm{a}} \pm 0.26$ & $13.41^{\mathrm{a}} \pm 0.26$ \\
$\mathrm{~b}^{*}$ & $10.79^{\mathrm{a}} \pm 0.28$ & $10.51^{\mathrm{a}} \pm 0.29$ & $11.00^{\mathrm{a}} \pm 0.29$ \\
Tenderness (N) & $63.50^{\mathrm{a}} \pm 1.93$ & $59.31^{\mathrm{a}} \pm 1.99$ & $59.33^{\mathrm{a}} \pm 1.95$ \\
Fat thickness caudal (mm) & $7.55^{\mathrm{a}} \pm 0.43$ & $8.61^{\mathrm{a}} \pm 0.44$ & $8.15^{\mathrm{a}} \pm 0.43$ \\
Fat thickness cranial (mm) & $8.53^{\mathrm{a}} \pm 0.50$ & $7.57^{\mathrm{a}} \pm 0.51$ & $8.28^{\mathrm{a}} \pm 0.50$ \\
Moisture (\%) & $56.4^{\mathrm{a}} \pm 1.19$ & $57.9^{\mathrm{a}} \pm 1.23$ & $55.6^{\mathrm{a}} \pm 1.21$ \\
Protein (\%) & $14.4^{\mathrm{a}} \pm 1.08$ & $12.4^{\mathrm{a}} \pm 1.12$ & $12.9^{\mathrm{a}} \pm 1.10$ \\
Fat (\%) & $24.0^{\mathrm{a}} \pm 1.57$ & $24.9^{\mathrm{a}} \pm 1.62$ & $27.6^{\mathrm{a}} \pm 1.59$ \\
Ash (\%) & $1.7^{\mathrm{a}} \pm 0.32$ & $2.7^{\mathrm{a}} \pm 0.33$ & $2.1^{\mathrm{a}} \pm 0.33$ \\
& & & \\
\hline
\end{tabular}

${ }^{\mathrm{a}, \mathrm{b}}$ Row means with different superscripts differ significantly $(P \leq 0.05)$.

Table 3 Least square means ( \pm s.e.) depicting the effect of the inclusion of the $\beta$-agonist on the meat quality of SA Mutton Merino feedlot lambs

\begin{tabular}{lcc}
\hline \multirow{2}{*}{ Parameters } & \multicolumn{2}{c}{$\boldsymbol{\beta}$-agonist } \\
\cline { 2 - 3 } & Absent & Included \\
\hline Drip loss (\%) & $0.8^{\mathrm{a}} \pm 0.03$ & $0.8^{\mathrm{a}} \pm 0.04$ \\
Cooking loss (\%) & $17.4^{\mathrm{a}} \pm 0.68$ & $16.7^{\mathrm{a}} \pm 0.68$ \\
$\mathrm{~L}^{*}$ & $36.59^{\mathrm{a}} \pm 0.40$ & $35.63 \pm 0.40$ \\
$\mathrm{a}^{*}$ & $13.49^{\mathrm{a}} \pm 0.21$ & $13.09^{\mathrm{a}} \pm 0.21$ \\
$\mathrm{~b}^{*}$ & $10.97^{\mathrm{a}} \pm 0.23$ & $10.57^{\mathrm{a}} \pm 0.23$ \\
Tenderness (N) & $59.84^{\mathrm{a}} \pm 1.58$ & $61.58^{\mathrm{a}} \pm 1.60$ \\
Fat thickness caudal (mm) & $8.46^{\mathrm{a}} \pm 0.35$ & $7.75^{\mathrm{a}} \pm 0.35$ \\
Fat thickness cranial (mm) & $8.36^{\mathrm{a}} \pm 0.41$ & $7.89^{\mathrm{a}} \pm 0.41$ \\
Moisture (\%) & $56.8^{\mathrm{a}} \pm 0.98$ & $56.4^{\mathrm{a}} \pm 0.99$ \\
Protein (\%) & $13.8^{\mathrm{a}} \pm 0.89$ & $12.6^{\mathrm{a}} \pm 0.90$ \\
Fat (\%) & $24.8^{\mathrm{a}} \pm 1.29$ & $26.2^{\mathrm{a}} \pm 1.30$ \\
Ash (\%) & $2.5^{\mathrm{a}} \pm 0.26$ & $1.8^{\mathrm{a}} \pm 0.27$ \\
\hline
\end{tabular}

${ }^{\mathrm{a}, \mathrm{b}}$ Row means with different superscripts differ significantly $(P \leq 0.05)$.

Meat quality and a number of production factors are influenced by the sex of the lamb (Rodriguez et al., 2008). In this study it was found that sex did indeed affect fat thickness, moisture-, protein-, lipid-, ash percentage as well as the tenderness of the meat (Table 4). The meat from ewe lambs was significantly fatter $(P<0.05)$ than rams' meat. Kirton et al. (1995) noted that ewe lambs deposit more total carcass fat and have larger individual fat depots when compared to ram lambs at the same age. According to Butterfield (1988), rams mature slower than ewes, while ewes fatten up earlier than the rams; the different maturation rate of the sexes influence the growth curves significantly (Crouse et al., 1981). Tejeda et al. (2008) concluded that 
meat from heavier lambs (less tender and more intense flavour) is considered to have lower quality than light lambs; fat is the source of flavour in meat (Thu, 2006). Johnson et al. (2005) also confirmed that the meat from ram lambs had higher shear values compared to ewe lambs, thus the meat from ram lambs is less tender than that from ewe lambs.

The ewe lambs had an average of $0.80 \mathrm{~mm}$ thicker SCF on the LD muscle than the ram lambs, whereas the ram lambs had a higher protein content than the ewe lambs.

Table 4 Least square means ( \pm s.e.) depicting the effect of gender on the meat quality of SA Mutton Merino feedlot lambs

\begin{tabular}{lcc}
\hline & \multicolumn{2}{c}{ Sex } \\
\cline { 2 - 3 } Physical Parameters & Ewe & Ram \\
\hline Drip loss (\%) & $0.80^{\mathrm{a}} \pm 0.04$ & $0.79^{\mathrm{a}} \pm 0.03$ \\
Cooking loss (\%) & $16.32^{\mathrm{a}} \pm 0.71$ & $17.71 \pm 0.65$ \\
$\mathrm{~L}^{*}$ & $35.92^{\mathrm{a}} \pm 0.43$ & $36.29^{\mathrm{a}} \pm 0.39$ \\
$\mathrm{a}^{*}$ & $13.49^{\mathrm{a}} \pm 0.22$ & $13.09^{\mathrm{a}} \pm 0.20$ \\
$\mathrm{~b}^{*}$ & $11.07^{\mathrm{a}} \pm 0.25$ & $10.47^{\mathrm{a}} \pm 0.23$ \\
Tenderness (N) & $57.82^{\mathrm{a}} \pm 1.69$ & $63.60^{\mathrm{b}} \pm 1.54$ \\
Fat thickness caudal (mm) & $8.47^{\mathrm{a}} \pm 0.37$ & $7.74 \pm 0.34$ \\
Fat thickness cranial (mm) & $8.58^{\mathrm{a}} \pm 0.43$ & $7.68^{\mathrm{a}} \pm 0.40$ \\
Moisture (\%) & $54.2^{\mathrm{a}} \pm 1.04$ & $59.0^{\mathrm{b}} \pm 0.95$ \\
Protein (\%) & $12.8^{\mathrm{a}} \pm 0.95$ & $13.7^{\mathrm{a}} \pm 0.87$ \\
Fat (\%) & $27.9^{\mathrm{a}} \pm 1.38$ & $23.1^{\mathrm{b}} \pm 1.26$ \\
Ash (\%) & $2.4^{\mathrm{a}} \pm 0.28$ & $2.0^{\mathrm{a}} \pm 0.26$ \\
\end{tabular}

${ }^{\mathrm{a}, \mathrm{b}}$ Row means with different superscripts differ significantly $(P \leq 0.05)$.

\section{Conclusion}

It was hypothesised that the meat from lambs receiving a high energy level diet would contain a higher fat percentage than lambs receiving a low energy level diet; however, no difference was found between the fat percentages of the lambs fed different dietary energy levels. The quality of the meat of the ewe lambs was better than the quality of the ram lambs in terms of their tenderness. On the other hand, the meat of the ewe lambs had a thicker SCF as well as a higher fat content in the $9-11^{\text {th }}$ rib-cut than the meat of ram lambs.

It was also hypothesised that the meat from the lambs that received the $\beta$-AA would be tougher than the meat from the lambs that did not receive the $\beta$-AA. However, no difference was found as pertaining to the tenderness of the lambs.

\section{References}

AOAC International, 2002. Official methods of analysis $17^{\text {th }}$ ed. Arlington, Virginia USA.

Butterfield, R.M., 1988. New Concepts of Sheep Growth. Australia: Department of Veterinary Anatomy University of Sydney, Australia.

Crouse, J.D., Busboom, J.M. \& Johnson, B.J., 2010. Perspective on the application of zilpaterol hydrochloride in the United States beef industry. J. Anim. Sci. 88, 2825-2828.

Ebrahimi, R., Ahmadi, H.R., Zamiri, M.J. \& Rowghani, E., 2007. Effect of energy and protein levels on feedlot performance and carcass characteristics of Mehraban ram lambs. Pakistan J. Bio. Sci. 10, 1679-1684.

Hopkins, D.L. \& Fogarty, N.M., 1998. Diverse lamb genotypes - 2.Meat pH, colour and tenderness. Meat Sci. 49, 477-488. 
Johnson, P.L., Purchas, R.W., McEwan, J.C. \& Blair, H.T., 2005. Carcass composition and meat quality differences between pasture-reared ewe and ram lambs. Meat Sci. 71, 383-391.

Kirton, A.H., Carter, A.H., Clarke, J.N., Sinclair, D.P., Mercer, G.J.K. \& Duganzich, D.M., 1995. A comparison between 15 ram breeds for export lamb production 1. Live weights, body composition, carcass measurements and composition. New Z. J. Agric. Res. 38, 347-360.

Kretchmar, D.H., Hathaway, M.R., Epley, R.J. \& Dayton, W.R., 1990. Alterations in post-mortem degradation of myofibrillar proteins in muscle of lambs fed a $\beta$-adrenergic agonist. J. Anim. Sci. 68, 1760-1772.

Lopez-Carlos, M.A., Ramirez, R.G., Aguilera-Soto, J.I., Arechiga, C.G., Mendez-Llorente, F. Rodriguez, H. \& Silva, J.M., 2010. Effect of ractopamine hydrochloride and zilpaterol hydrochloride on growth, diet digestibility, intake and carcass characteristics of feedlot lambs. Livest. Sci. 131, 23-30.

Mersmann, J.J., 1998. Overview of the effects of $\beta$-adrenergic receptor agonists on animal growth including mechanism of action. J. Anim. Sci. 76, 160-172.

Mersmann, J.J., 2002. Beta-adrenergic receptor modulation of adipocyte metabolism and growth. J. Anim. Sci. 80, 24-29.

O'Neill, H.A., 2001. The effect of zilpaterol hydrochloride on dietary N-requirements and the quality and nutritional value of meat components. MSc (Agric) thesis, University of Pretoria, South Africa.

Rodriguez, A.B., Landa, R., Bodas, R., Prieto, N., Mantecon, A.R. \& Giraldez, F.J., 2008. Carcass and meat quality of Assaf milk fed lambs: Effect of rearing system and sex. Meat Sci. 80, 225-230.

Safari, E., Fogarty, N.M., Ferrier, G.R., Hopkins, L.D. \& Gilmour, A., 2001. Diverse lamb genotypes. 3. Eating quality and the relationship between its objective measurement and sensory assessment. Meat Sci. 57, 153-159.

SAS, 2000. SAS/STAT Users guide, First Edition, Volume 2. SAS Inst. Inc., Cary, North Carolina, USA.

Shapiro, S.S. \& Wilk, M.B., 1965. An analysis of variance test for normality (complete samples). Biometrika 52, 591-611.

Shelver, W.L. \& Smith, D.J., 2006. Tissue residues and urinary excretion of Zilpaterol in sheep treated for 10 days with dietary Zilpaterol. J. Agric. Food Chem. 54, 4155-4161.

Wheeler, T.L. \& Koohmaraie, M., 1992. Effects of the $\beta$-adrenergic agonist $\mathrm{L}_{644,969}$ on muscle protein turnover, endogenous proteinase activities, and meat tenderness in steers. J. Anim. Sci. 70, 3035-3043.

Summers, R.L., Kemp, J.D., Ely, D.G. \& Fox, J.D., 1978. Effects of weaning, feeding systems and sex of lamb on lamb carcass characteristics and palatability. J. Anim. Sci. 47, 622-631.

Tejeda, J.F., Pena, R.E. \& Andres, A.I., 2008. Effect of live weight and sex on physic-chemical and sensorial characteristics of merino lamb meat. Meat Sci. 80, 1061-1067.

Thu, D.T.N., 2006. Meat quality: understanding of meat tenderness and influence of fat content on meat flavour. Science and Technology Development 9, 65-70. 